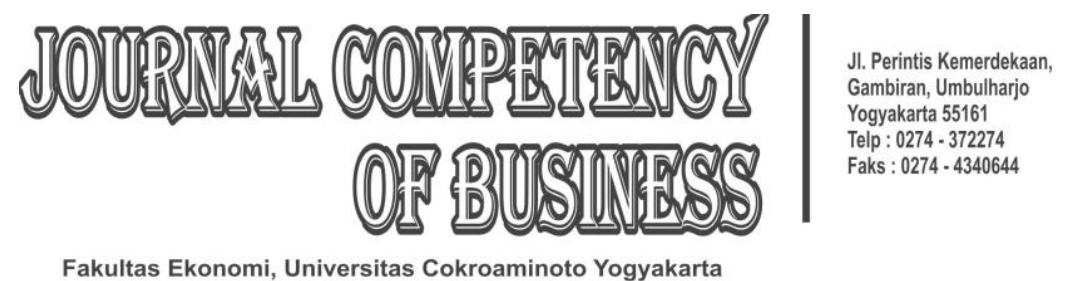

\title{
PENGARUH KOMPENSASI DAN LINGKUNGAN KERJA TERHADAP KEPUASAN KERJA KARYAWAN PT. ESTADANA VENTURE CABANG KOTABUNAN SULAWESI UTARA
}

\author{
Susindra Katili ${ }^{1}$ Heri Prasetyo ${ }^{2}$ \\ ${ }^{1,2}$ Program Studi Manajemen Fakultas Ekonomi \\ Universitas Cokroaminoto Yogyakarta \\ 1,2 susindra_katili@gmail.com, heriprasucy@gmail.com
}

\begin{abstract}
ABSTRAK
Penelitian ini bertujuan untuk mengetahui pengaruh kompensasi dan lingkungan kerja terhadap kepuasan kerja karyawan PT. Estadana Venture Cabang Kotabunan Sulawesi Utara. Jenis penelitian yang digunakan dalam penelitian ini adalah penelitian kuantitatif. Sampel adalah bagian dari jumlah dan karakteristik yang dimiliki oleh populasi tersebut. Berdasarkan jumlah populasi karyawan PT. Estadana Venture CabangKotabunan Sulawesi Utara sebanyak 34 orang maka peneliti mengambil keseluruhan populasi tersebut untuk dijadikan sampel penelitian. Hasil penelitian ini menunjukkan bahwa kompensasi berpengaruh signifikan terhadap kepuasan kerja karyawan PT. Estadana Venture Cabang Kotabunan Sulawesi Utara; lingkungan kerja berpengaruh signifikan terhadap kepuasan kerja karyawan PT. Estadana Venture Cabang Kotabunan Sulawesi Utara serta sebesar 43,4\% kepuasan kerja karyawan PT. Estadana Venture Cabang Kotabunan Sulawesi Utara dapat dijelaskan oleh variabel kompensasi dan lingkungan kerja. Sedangkan sisanya sebesar $56,6 \%$ dipengaruhi variabel lain yang tidak di ada dalam penelitian
\end{abstract}

Kata Kunci: Kompensasi, lingkungan kerja dan kepuasan kerja

ABSTRACT
This study aims to determine the effect of compensation and work
environment on job satisfaction of employees of PT. Estadana Venture,
Kotabunan Branch, North Sulawesi. The type of research used in this
research is quantitative research. The sample is part of the number and
characteristics possessed by the population. Based on the total employee
population of PT. Estadana Venture Branch Kotabunan North Sulawesi as
many as 34 people, the researchers took the total population to be used as
research samples. The results of this study indicate that compensation has
48

E-ISSN: 2777-1156

2021. Vol 5. No 1 
a significant effect on job satisfaction of employees of PT. Estadana Venture Kotabunan Branch, North Sulawesi; work environment has a significant effect on job satisfaction of employees of PT. Estadana Venture Kotabunan Branch, North Sulawesi and $43.4 \%$ job satisfaction of employees of PT. Estadana Venture Branch Kotabunan North Sulawesi can be explained by the variables of compensation and work environment. While the remaining $56.6 \%$ the influence of other variables that are not in the study

Keywords: Compensation, work environment and job satisfaction

\section{PENDAHULUAN}

Lembaga keuangan menjadi salah satu faktor penggerak perekonomian di Indonesia. Ada dua jenis lembaga keuangan yaitu lembaga keuangan Bank dan Non-Bank. Lembaga keuangan non bank adalah Semua badan yang melakukan kegiatan di bidang keuangan, yang secara langsung atau tidak langsung menghimpun dana terutama dengan jalan mengeluarkan kertas berharga dan menyalurkan dalam masyarakat terutama guna membiayai investasi perusahaan. Manfaat dari lembaga keuangan bukan bank ini adalah membantu menggerakkan sistem perekonomian masyarakat, khususnya melayani kebutuhan ekonomi masyarakat yang tidak bisa dijangkau oleh fungsi lembaga perbankan. Sedangkan menurut UU No. 10 Tahun 1998, bank umum adalah bank yang melaksanakan kegiatan usaha secara konvensional atau berdasarkan prinsip syariah yang kegiatanya memberikan jasa dalam lalu lintas pembayaran.

Setiap lembaga keuangan menggunakan sumber daya manusia untuk menjalankan perusahaannya, termasuk juga Esta Dana Ventura yang menggunakan sumber daya manusia untuk menjalankan perusahaannya. Sumber daya manusia yang disingkat menjadi SDM merupakan kemampuan yang dimiliki setiap manusia. SDM terdiri dari daya fikir dan daya fisik setiap manusia maka kemampuan setiap manusia dapat ditentukan oleh daya pikir dan daya fisiknya. Keberhasilan suatu perusahaan itu tidak lepas dari adanya sumber daya manusia (karyawan) yang kompeten dan berkualitas yang menjalankan semua sistem yang ada di dalam perusahaan tersebut. Oleh karena itu perusahaan dituntut untuk mengelola dan mengoptimalkan sumber daya manusia serta memperhatikan kesejahteraan karyawannya. Sumber daya manusia sifatnya sangat kompleks sehingga perlu mendapatkan perhatian, penanganan dan perlakuan khusus di samping faktor yang lain karena perannya sebagai subyek pelaksana kebijakan dan kegiatan operasional perusahaan agar sejalan dengan tujuan organisasi itu sendiri. Sejalan dengan pentingnya sumber daya manusia dalam organisasi, manusia merupakan unsur yang paling penting menentukan keberhasilan atau 
kegagalan suatu organisasi dalam menyelenggarakan berbagai kegiatannya dan dalam rangka pencapaian tujuan dan sasaran instansi/organisasi (Siagian, 2007).

Salah satu yang harus diperhatikan terhadap para karyawannya adalah kepuasan kerja para karyawan. Mathis dan Jackson (2001) mendefinisikan kepuasan kerja sebagai keadaan emosi yang positif dari mengevaluasi pengalaman kerja seseorang sedangkan ketidakpuasan akan muncul ketika harapan-harapan mereka tidak terpenuhi. Kepuasan kerja memiliki efek kepada kehidupan organisasi. Kepuasan kerja/job satisfaction adalah sikap/attitudes positif atau negatif yang dimiliki seorang karyawan terhadap pekerjaannya. Sikap ini merupakan hasil persepsi karyawan terhadap pekerjaannya. Seorang karyawan yang memiliki tingkat kepuasan kerja tinggi menunjukkan sikap yang positif terhadap pekerjaannya, sedangkan karyawan yang memiliki tingkat kepuasan kerja rendah menunjukkan sikap yang negatif terhadap pekerjaannya. Kepuasan kerja menunjukkan suatu sikap bukan perilaku. Kepuasan kerja yang tinggi diharapkan membuat karyawan menjadi semakin setia kepada organisasi, semakin termotivasi dalam bekerja, merasa senang dalam bekerja, dan pada gilirannya akan meningkatkan produktivitas. Karyawan yang tidak puas cenderung menghindar dari tugas dan tanggungjawab, yang akan mengganggu proses pencapaian tujuan organisasi. Karyawan yang puas memiliki kesehatan yang lebih baik, usia yang lebih panjang, dan kepuasan kerja tersebut akan dibawa ke luar dari organisasi.

Kepuasan Kerja Karyawan sendiri dapat dimotivasi oleh perusahaan dengan memberikan kompenasi sesuai dengan kontribusi yang diberikan kepada perusahaan, menciptakan lingkungan kerja yang kondusif dan budaya perusahaan yang baik. Kompensasi adalah segala sesuatu yang diterima karyawan sebagai balas jasa atas kerja mereka (Handoko, 2005). Pemberian kompensasi diharapkan karyawan dapat lebih bersemangat dan bekerja lebih giat untuk meningkatkan kinerjanya masing-masing, sehingga produktivitas perusahaan dapat meningkat. Sejalan dengan penelitian Febriana Dewi (2012) yang berjudul "Pengaruh Kepemimpinan, Kompensasi dan Budaya Organisasi terhadap Kepuasan kerja karyawan" menunjukkan hasil variabel kompensasi mempunyai pengaruh yang signifikan dan positif terhadap kepuasan kerja karyawan.

Selain kompensasi, variabel lain yang mempengaruhi kepuasan kerja adalah lingkungan kerja. Lingkungan kerja merupakan kondisi dari segala sesuatu yang terdapat di sekitar tempat bekerja karyawan yang mampu memberikan pengaruh bagi dirinya dalam melaksanakan pekerjaannya (Nitisemito, 2006:106). Kondisi lingkungan kerja yang tidak sehat dapat menyebabkan para karyawan mudah stres, tidak semangat untuk bekerja, datang terlambat, demikian juga sebaliknya apabila lingkungan kerja itu sehat maka para karyawan tentunya akan semangat dalam bekerja, tidak mudah sakit, mudah untuk konsentrasi sehingga pekerjaan menjadi cepat selesai sesuai dengan target. Sejalan dengan penelitian Tegar 
Fakultas Ekonomi, Universitas Cokroaminoto Yogyakarta

Mangkulangit (2014) dengan judul "Pengaruh lingkungan kerja, kompensasi dan kepemimpinan terhadap kepuasan kerja karyawan pada PT. BPR Weleri Jayapersada Kendal". Menunjukkan lingkungan kerja berpengaruh positif dan signifikan terhadap kepuasan kerja karyawan pada PT. BPR Weleri Jayapersada Kendal.

\section{KAJIAN PUSTAKA \\ 1. Kepuasan Kerja}

Menurut Handoko (1995), kepuasan kerja adalah keadaan emosional baik yang menyenangkan maupun tidak menyenangkan dimana karyawan memandang pekerjaan mereka. Mathis dan Jackson (2001) mendefinisikan kepuasan kerja sebagai keadaan emosi yang positif dari mengevaluasi pengalaman kerja seseorang. Ketidakpuasan akan muncul ketika harapan-harapan mereka tidak terpenuhi. Sedangkan menurut As'ad (2000) kepuasan kerja adalah perasaan seorang karyawan terhadap pekerjaannya. Kepuasan kerja merupakan hasil interaksi antara karyawan dengan tempat kerja mereka. Setiap individu akan memiliki tingkat keupasan kerja yang berbeda-beda sesuai dengan nilai-nilai yang dianut pada dirinya. Kepuasan kerja memiliki efek kepada kehidupan organisasi. Kepuasan kerja/job satisfaction adalah sikap/attitudes positif atau negatif yang dimiliki seorang karyawan terhadap pekerjaannya.

Kepuasan kerja adalah perasaan senang atau emosi positif sebagai hasil persepsi pengalaman selama masa kerja seseorang. Kepuasan kerja berkaitan dengan kondisi masa lalu, bukan masa yang akan datang. Berdasarkan definisi ini ada tiga aspek yang berkaitan dengan kepuasan kerja:

1. Kepuasan kerja merupakan fungsi dari nilai-nilai/values apa yang diinginkan individu secara sadar atau tidak untuk diraih

2. Masing-masing karyawan memiliki pandangan yang berbeda tentang nilai mana yang penting dalam menentukan bentuk dan kepuasan kerja

3. Persepsi seseorang mengenai keadaan sekarang berhubungan dengan nilai-nilai yang berarti bagi individu

Lima model kepuasan kerja, yang dikemukakan oleh Kreitner \& Kinichi (2005) adalah:

1. Pertama pemenuhan kebutuhan, model ini menjelaskan bahwa kepuasan ditentukan oleh karakteristik dari sebuah pekerjaan yang memungkinkan seseorang dapat memenuhi kebutuhannya.

2. Kedua ketidakcocokan, model ini menjelaskan bahwa kepuasan adalah hasil dari harapan yang terpenuhi.

3. Ketiga pencapaian nilai, model ini menjelaskan bahwa kepuasan berasal dari persepsi bahwa suatu pekerjaan memungkinkan untuk pemenuhan nilai-nilai kerja yang penting dari individu.

4. Keempat persamaan, model ini kepuasan adalah suatu fungsi dari bagaimana seorang individu diperlakukan ditempat kerja. 
Fakultas Ekonomi, Universitas Cokroaminoto Yogyakarta

5. Kelima watak atau genetik, model ini berusaha menjelaskan beberapa orang merasa puas dengan situasi dan kondisi kerja tertentu, namun sebagian lagi merasa tidak puas dengan kondisi tersebut.

Adapun indikator yang dimaksud adalah sebagai berikut:

1. Menyenangi Pekerjaannya. Salah satu indikator terkait job satisfaction adalah menyenangi pekerjaan. Seorang pekerja secara sadar sudah memilih jenis pekerjaan yang ia ambil, mengetahui cara bagaimana ia bekerja dan beragam hal lainnya. Jika ia mampu mengerjakannya dengan baik, maka ia sudah termasuk menyenangi pekerjaannya tersebut.

2. Mencintai Pekerjaan. Kepuasan senantiasa in line dengan cinta. Dalam hal ini, kepuasan kerja seorang karyawan bisa dinilai dari bagaimana ia mencintai pekerjaan yang ia miliki dan lakukan. Indikator ini menunjukkan bahwa seorang karyawan yang merasa puas dengan pekerjaannya maka ia akan senantiasa bekerja dengan penuh cinta dan semangat.

3. Moral Kerja Positif. Indikator lain yang menjadi tolak ukur job satisfaction adalah moral kerja positif. Moral kerja ini beranjak dari dua indikator sebelumnya. Jika seorang karyawan menyenangi dan mencintai pekerjaan yang ia miliki, maka moral kerja yang ia miliki pasti akan senantiasa positif dan target yang dicapai senantiasa maksimal.

4. Disiplin Kerja. Kondisi emosional yang puas karena pekerjaan akan membentuk pola disiplin yang lebih baik. Jika seorang karyawan tampak menunjukkan nilai ketaatan, kepatuhan, kesetiaan, keteraturan atau ketertiban, maka ia sudah mendapatkan kepuasan dalam pekerjaan yang dimiliki.

5. Prestasi Kerja. Kepuasan dalam pekerjaan juga bisa dilihat dari prestasi yang didapatkan. Dalam hal ini, seorang karyawan yang merasakan job satisfaction akan cenderung lebih berprestasi daripada mereka yang tidak mendapatkan kepuasan dalam pekerjaan yang mereka miliki.

\section{Kompensasi}

Kompensasi adalah segala sesuatu yang diterima karyawan sebagai balas jasa atas kerja mereka (Handoko, 2005). Menurut Mathis dan Jackson (2002) kompensasi/imbalan dapat berbentuk intrinsik/internal seperti pujian, termasuk dampak psikologis dari pemberian kompensasi, dan ekstrinsik/eksternal yang bersifat terukur, dapat berbentuk moneter maupun nonmoneter. Kompensasi adalah semua pendapatan yang berbentuk uang atau barang langsung maupun tidak langsung yang diterima oleh karyawan sebagai imbalan atas jasa mereka yang diberikan kepada organisasi. 
Fakultas Ekonomi, Universitas Cokroaminoto Yogyakarta

Kompensasi merupakan hal yang penting baik bagi organisasi/perusahaan maupun bagi karyawan. Bagi organisasi kompensasi memiliki berbagai macam tujuan antara lain untuk menarik calon karyawan agar bergabung ke dalam organisasi, memotivasi karyawan, dan meningkatkan kepuasan kerja. Sedangkan bagi karyawan kompensasi merupakan sumber penghasilan untuk kelangsungan hidup secara ekonomis dan menentukan status sosial dalam masyarakat. Kompensasi ini mencakup tiga komponen yaitu:

1. Direct financial payment, seperti gaji, upah, insentif, bonus, dan komisi;

2. Indirect payment, yaitu dalam bentuk tunjangan-tunjangan misalnya asuransi kesehatan, tunjangan keluarga, cuti kerja, program rekreasi, pensiun, koperasi simpan pinjam, transport dan sebagainya

3. Imbalan nonfinansial, yaitu hal-hal yang sulit untuk dikuantifikasi seperti jam kerja yang lebih fleksibel, tugas atau pekerjaan yang menantang, dan fasilitas kantor yang bergengsi.

Menurut Simamora (2004), indikator untuk mengukur kompensasi karyawan diantaranya sebagai berikut:

1. Upah dan gaji, Upah adalah basis bayaran yang seringkali digunakan bagi para pekerja produksi dan pemeliharaan. Upah pada umumnya berhubungan dengan tarif gaji per jam dan gaji biasanya berlaku untuk tarif bayaran tahunan, bulanan atau mingguan.

2. Insentif, Pengertian Insentif adalah tambahan kompensasi di atas atau di luar gaji atau upah yang diberikan oleh perusahaan.

3. Tunjangan, Pengertian Tunjangan adalah asuransi kesehatan dan jiwa, program pensiun, liburan yang ditanggung perusahaan, dan tunjangan lainnya yang berkaitan dengan hubungan kepegawaian.

4. Fasilitas, Pengertian Fasilitas adalah pada umumnya berhubungan dengan kenikmatan seperti mobil perusahaan, akses ke pesawat perusahaan, tempat parkir khusus dan kenikmatan (baca: perlakuan khusus) yang diperoleh karyawan.

\section{Lingkungan Kerja}

Menurut Sutrisno (2012:118), lingkungan kerja adalah keseluruhan sarana dan prasarana kerja yang ada di sekitar karyawan yang sedang melakukan pekerjaan yang dapat mempengaruhi pelaksanaan pekerjaan. Menurut Nitisemito dalam Khoiriyah (2009:24) lingkungan kerja adalah segala sesuatu yang ada disekitar para pekerja dan dapat memengaruhi dirinya dalam menjalankan tugas yang dibebankan. Menurut Sedarmayanti dalam Wulan (2011:21), menyatakan bahwa secara garis besar, jenis lingkungan kerja terbagi menjadi 2 yaitu lingkungan kerja fisik dan lingkungan kerja non fisik. Menurut Sukanto dan Indriyo dalam Khoiriyah (2009:24) lingkungan kerja adalah segala sesuatu yang ada disekitar pekerja yang dapat memengaruhi dalam bekerja meliputi pengaturan 
Fakultas Ekonomi, Universitas Cokroaminoto Yogyakarta

penerangan, pengontrolan suara gaduh, pengaturan kebersihan tempat kerja dan pengaturan keamanan tempat kerja. Lingkungan kerja merupakan kondisi dari segala sesuatu yang terdapat di sekitar tempat bekerja karyawan yang mampu memberikan pengaruh bagi dirinya dalam melaksanakan pekerjaannya (Nitisemito, 2006:106). Pengertian lain lingkungan kerja adalah segala sesuatu yang ada di sekitar para pekerja dan yang dapat mempengaruhi dirinya dalam menjalankan tugas-tugas yang dibebankan (Sunyoto,2012:43).

Sedarmayanti (2004:46) menyatakan terdapat indikator lingkungan kerja, antara lain:

1. Penerangan atau cahaya pada tempat kerja

2. Temperatur atau suhu udara pada tempat kerja

3. Kelembapan udara pada tempat kerja

4. Sirkulasi udara pada tempat kerja

5. Getaran mekanis pada tempat kerja

6. Bau tidak sedap pada tempat kerja

7. Tata warna pada tempat kerja

8. Dekorasi pada tempat kerja

9. Musik pada tempat kerja

10. Keamanan pada tempat kerja

\section{Kerangka Pemikiran}

Kerangka pemikiran adalah suatu diagram yang menjelaskan secara garis besar alur logika berjalannya sebuah penelitian.

Gambar 1. Kerangka Pemikiran

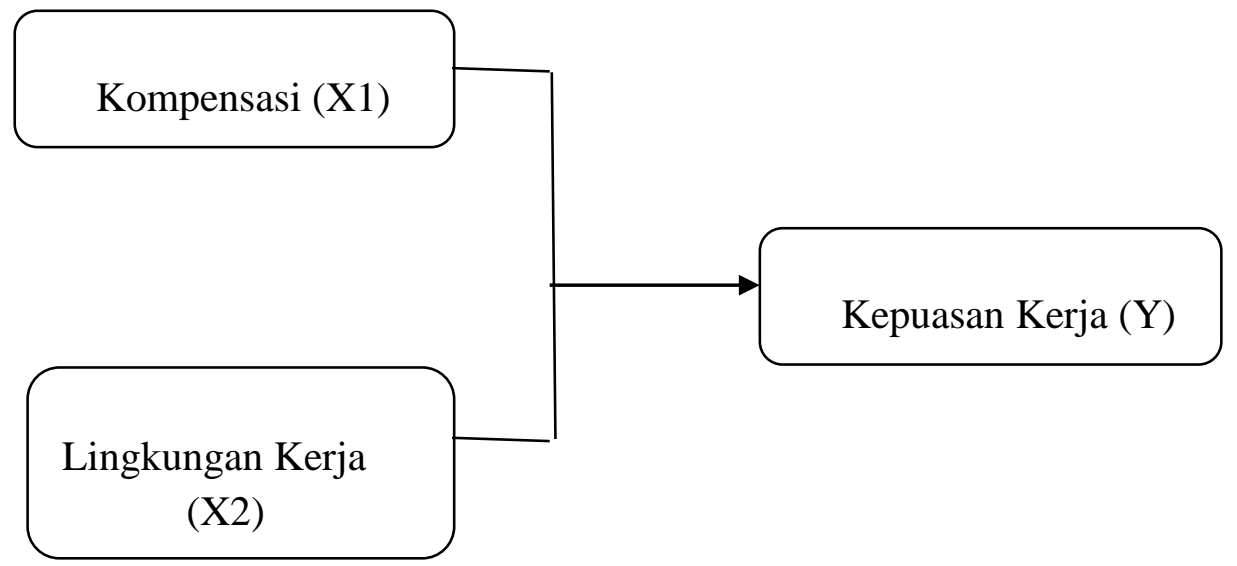

\section{Hipotesis Penelitian}

1. Pengaruh kompensasi (X1) terhadap kepuasan kerja (Y)

Kompensasi adalah segala sesuatu yang diterima karyawan sebagai balas jasa atas kerja mereka (Handoko, 2005). Dengan adanya sistem kompensasi yang baik adalah yang mampu menjamin kepuasan para karyawan, sehingga organisasi akan memperoleh, memelihara serta mempekerjakan sejumlah karyawan yang dengan berbagai sikap dan 
perilaku positif bekerja dengan produktif bagi kepentingan organisasi (Sunyoto,2012:30). Berdasarkan hubungan diatas maka hipotesis dalam penelitian ini adalah:

H1: Kompensasi berpengaruh signifikan terhadap terhadap kepuasan kerja karyawan PT. Estadana Venture Cabang Kotabunan Sulawesi Utara.

2. Pengaruh lingkungan kerja (X2) terhadap kepuasan kerja (Y)

Menurut Sutrisno (2012:118), lingkungan kerja adalah keseluruhan sarana dan prasarana kerja yang ada di sekitar karyawan yang sedang melakukan pekerjaan yang dapat mempengaruhi pelaksanaan pekerjaan. Setiap karyawan selalu mengharapkan lingkungan kerja yang akrab, nyaman dan saling mendukung. Oleh karena itu karyawan mengharapkan lingkungan kerja dimana sarana dan prasarana kerja lengkap dan baik. Lingkungan baik bisa menimbulkan rasa bangga, rasa aman, dan menciptakan hubungan yang harmoni sehingga kebutuhan afiliasi karyawan terpenuhi. Berdasarkan hubungan diatas maka hipotesis dalam penelitian ini adalah:

H2: Lingkungan Kerja berpengaruh signifikan terhadap terhadap kepuasan kerja karyawan PT. Estadana Venture Cabang Kotabunan Sulawesi Utara.

3. Pengaruh kompensasi (X1) dan lingkungan kerja (X2) terhadap kepuasan kerja (Y)

Dengan adanya sistem kompensasi yang baik adalah yang mampu menjamin kepuasan para karyawan, sehingga organisasi akan memperoleh, memelihara serta mempekerjakan sejumlah karyawan yang dengan berbagai sikap dan perilaku positif bekerja dengan produktif bagi kepentingan organisasi (Sunyoto,2012:30) lalu apabila setiap anggota organisasi berperilaku sesuai dengan budaya yang berlaku maka akan diterima oleh lingkungannya sehingga akan menimbulkan kepuasan untuk bekerja secara optimal. Berdasarkan hubungan diatas maka hipotesis dalam penelitian ini adalah:

H3: Kompensasi dan ingkungan Kerja berpengaruh signifikan terhadap terhadap kepuasan kerja karyawan PT. Estadana Venture Cabang Kotabunan Sulawesi Utara.

\section{METODE PENELITIAN}

\section{Jenis Penelitian}

Penelitian ini merupakan jenis penelitian kuantitatif. Penelitian kuantitatif adalah suatu proses menemukan pengetahuan yang menggunakan data berupa angka sebagai alat meganalisis keterangan mengenai apa yang ingin diketahui (Kasiram 2008:149). Metode penelitian kuantitatif merupakan salah satu jenis penelitian yang spesifikasinya adalah sistematis, terencana, dan terstruktur dengan jelas sejak awal hingga pembuatan desain penelitiannya. 


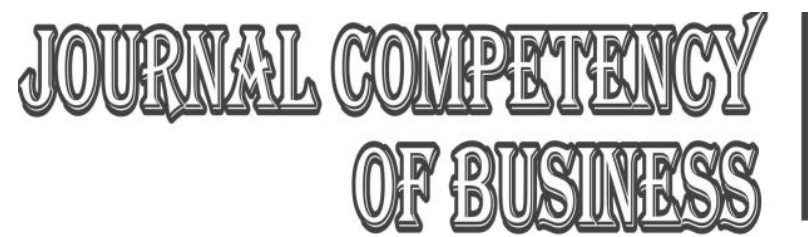

Fakultas Ekonomi, Universitas Cokroaminoto Yogyakarta

\section{Definisi Operasional Variabel}

\section{Kompensasi}

Kompensasi adalah segala sesuatu yang diterima karyawan sebagai balas jasa atas kerja mereka (Handoko, 2005). Menurut Simamora (2004), indikator mengukur kompensasi karyawan diantaranya sebagai berikut:
a. Upah dan gaji
b. Insentif.
c. Tunjangan.
d. Fasilitas.

\section{Lingkungan Kerja}

Menurut Sutrisno (2012:118), lingkungan kerja adalah keseluruhan sarana dan prasarana kerja yang ada di sekitar karyawan yang sedang melakukan pekerjaan yang dapat mempengaruhi pelaksanaan pekerjaan. Sedarmayanti (2004:46) menyatakan terdapat indikator lingkungan kerja, antara lain:
a. Penerangan atau cahaya pada tempat kerja
b. Temperatur atau suhu udara pada tempat kerja
c. Kelembapan udara pada tempat kerja
d. Sirkulasi udara pada tempat kerja
e. Getaran mekanis pada tempat kerja
f. Bau tidak sedap pada tempat kerja
g. Tata warna pada tempat kerja
h. Dekorasi pada tempat kerja
i. Musik pada tempat kerja
j. Keamanan pada tempat kerja

3. Kepuasan Kerja.

Menurut As'ad (2000) kepuasan kerja adalah perasaan seorang karyawan terhadap pekerjaannya. Adapun indikatornya adalah sebagai berikut:

a. Menyenangi Pekerjaannya.

b. Mencintai Pekerjaan.

c. Moral Kerja Positif.

d. Disiplin Kerja.

e. Prestasi Kerja.

\section{Populasi dan Sampel}

1. Populasi

Menurut Sugiyono (2010:117) Populasi adalah wilayah generalisasi yang terdiri atas obyek atau subyek yang mempunyai kuantitas dan karakteristik tertentu yang ditetapkan oleh peneliti untuk dipelajari dan kemudian ditarik kesimpulannya. Populasi dalam penelitian ini adalah karyawan PT. Estadana Venture CabangKotabunan Sulawesi Utara sebanyak 34 orang.

E-ISSN: 2777-1156 


\section{Sampel}

Menurut Sugiyono (2010:118) Sampel adalah bagian dari jumlah dan karakteristik yang dimiliki oleh populasi tersebut. Berdasarkan jumlah populasi karyawan PT. Estadana Venture CabangKotabunan Sulawesi Utara sebanyak 34 orang maka peneliti mengambil keseluruhan populasi tersebut untuk dijadikan sampel penelitian.

\section{Teknik Pengumpulan Data}

Teknik pengumpulan data dalam penelitian ini adalah denggan menggunakan kuesioner (angket). Kuesioner merupakan teknik pengumpulan data ayng dilakukan dengan cara memberi seperangkat petanyaan atau pernyataan tertulis kepada responden untuk dijawab. Pengambilan Sampel dilakukan dengan cara total sampling atau sampel jenuh atau juga disebut dengan sampel sensus, adalah teknik sampling yang dilakukan dengan mengambil seluruh populasi (Sugiyono,2010:122). Jumlah sampel yang diambil adalah 34 responden.

\section{Uji Hipotesis}

1. Analisis Regresi Linear Berganda

Menurut Sugiyono (2013: 275) analisis regresi linier berganda digunakan untuk meramalkan keadaan (naik turunnya) variabel dependen, jika dua atau lebih variabel independen sebagai faktor prediktor dimanipulasi (dinaik turunkan nilainya). Model analisis ini dipilih karena penelitian ini dirancang untuk meneliti variabel bebas yang berpengaruh terhadap variabel terikat. Untuk menguji hipotesis digunakan alat uji model statistik yang menggunakan analisis regresi linear ganda (multipleregression) dengan model sebagai berikut:

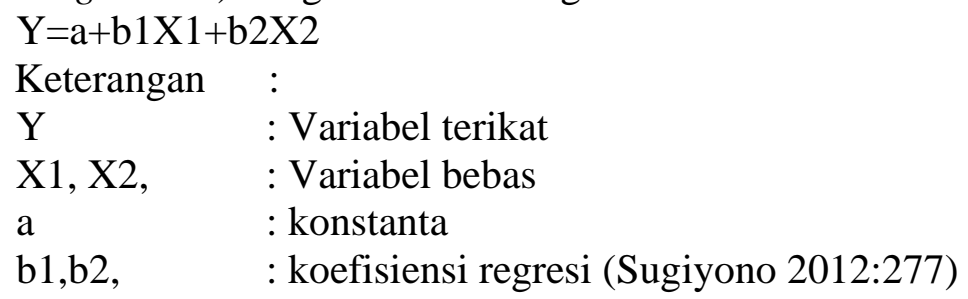

\section{PEMBAHASAN}

Berdasarkan deskripsi responden penelitian, karyawan PT. Estadana Venture Cabang Kotabunan Sulawesi Utara dari 34 karyawan mayoritas wanita yaitu sebanyak 34 orang dan pria 10 orang. Usia karyawan mayoritas 25-40 tahun yaitu sebanyak 19 orang sedangkan dibawah 25 tahun 12 orang dan diatas 40 tahun 3 orang. Pendidikan karywan matoritas SMA/SMK yaitu sebanyak 23 orang sedangkan diploma/sarjana 11 orang. 
Fakultas Ekonomi, Universitas Cokroaminoto Yogyakarta

Hasil uji instrumen penelitian menunjukkan seluruh pertanyaan dalam kuesioner valid atau sah dan variabel dalam penelitian ini reliabel atau handal untuk digunakan dalam penelitian.

Hasil uji regresi linear berganda diketahui persamaan regresi linear berganda $\mathbf{Y}=\mathbf{2 . 0 8 5 + 0 . 2 6 6 X 1 + 0 . 5 7 0 X 2}$. Dari persamaan tersebut dapat dijelaskan bahwa a) Nilai contant 2.085, artinya jika kompensasi dan lingkungan kerja nilainya adalah 0 ( Nol) maka kepusan kerja nilainya 2.085, b) Koefisien regresi variabel kompensasi (X1) 0.266, artinya jika kompensasi mengalami kenaikan satu angka maka kepuasan kerja mengalami kenaikan sebesar 0.266. koefisien memiliki nilai positif artinya terjadi hubungan positif antara kompensasi dan kepuasan kerja. Semakin baik kompensasi yang diberikan maka semakin tinggi kepuasan kerja karyawan PT. Estadana Venture Cabang Kotabunan Sulawesi Utara, c) Koefisien regresi variabel lingkungan kerja (X2) 0.570, artinya jika lingkungan kerja mengalami kenaikan satu angka maka kepuasan kerja mengalami kenaikan sebesar 0.570. koefisien memiliki nilai positif artinya terjadi hubungan positif antara lingkungan kerja dan kepuasan kerja. Semakin baik lingkungan kerja yang dirasakan karyawan maka semakin tinggi kepuasan kerja karyawan PT. Estadana Venture Cabang Kotabunan Sulawesi Utara.

Hasil uji t (uji parsial) diketahui pengaruh variabel kompensasi dan lingkungan kerja terhadap variabel kepuasan kerja sebagai berikut ini:

1. Kompensasi memiliki nilai sig signifikansi (sig) sebesar $0.030<0,05$ dan t hitung 2.281 lebih besar dari t tabel 2.039, maka dinyatakan bahwa variabel kompensasi berpengaruh singnifikan terhadap kepuasan kerja karyawan PT. Estadana Venture Cabang Kotabunan Sulawesi Utara. Dengan adanya sistem kompensasi yang baik adalah yang mampu menjamin kepuasan para karyawan, sehingga organisasi akan memperoleh, memelihara serta mempekerjakan sejumlah karyawan yang dengan berbagai sikap dan perilaku positif bekerja dengan produktif bagi kepentingan organisasi (Sunyoto,2012:30). Hasil tersebut sesuai dengan penelitian Tegar Mangkulangit (2014) yang berjudul Pengaruh Lingkungan Kerja, Kompensasi Dan Kepemimpinan Terhadap Kepuasan Kerja Karyawan Pada PT. BPR Weleri Jayapersada Kendal, dari hasil penelitian diketahui kompensasi berpengaruh positif dan signifikan terhadap kepuasan kerja Karyawan Pada PT. BPR Weleri Jayapersada Kendal.

2. Lingkungan kerja memiliki nilai sig signifikansi (sig) sebesar $0.000<$ 0,05 dan t hitung 4.509 lebih besar dari t tabel 2.039, maka dinyatakan bahwa variabel lingkungan kerja berpengaruh singnifikan terhadap kepuasan kerja karyawan PT. Estadana Venture Cabang Kotabunan Sulawesi Utara. Setiap karyawan selalu mengharapkan lingkungan kerja yang akrab, nyaman dan saling mendukung. Oleh karena itu karyawan mengharapkan lingkungan kerja dimana sarana dan prasarana kerja lengkap dan baik. Lingkungan baik bisa menimbulkan rasa bangga, rasa aman, dan menciptakan hubungan yang harmoni sehingga kebutuhan afiliasi karyawan terpenuhi. Hasil tersebut sesuai dengan penelitian Yoky

E-ISSN: 2777-1156

2021. Vol 5. No 1 
Fakultas Ekonomi, Universitas Cokroaminoto Yogyakarta

Suryo Prayogo (2015) berjudul Analisis Pengaruh Lingkungan Kerja Dan Budaya Organisasi Terhadap Kepuasan Kerja Karyawan RSI Sultan Agung Semarang, dari hasil penelitian diketahui lingkungan kerja berpengaruh positif terhadap kepuasan kerja karyawan RSI Sultan Agung Semarang.

3. Variabel paling mempengaruhi lingkungan kerja karyawan PT. Estadana Venture Cabang Kotabunan Sulawesi Utara adalah lingkungan kerja, dapat dilihat dari nilai t hitung paling besar yaitu 4.509 dan nilai signifikansi paling rendah yaitu 0.000 .

Hasil uji F (uji simultan) diketahui nilai signifikansi (sig) sebesar $0.000<0,05$ dan $\mathrm{F}$ hitung 13.632 lebih besar dari t tabel 3.30, maka dinyatakan bahwa variabel kompensasi dan lingkungan kerja secara bersama-sama berpengaruh singnifikan terhadap kepuasan kerja karyawan PT. Estadana Venture Cabang Kotabunan Sulawesi Utara. Dengan adanya sistem kompensasi yang baik dan yang mampu menjamin kepuasan para karyawan, sehingga organisasi akan memperoleh, memelihara serta mempekerjakan sejumlah karyawan yang dengan berbagai sikap dan perilaku positif bekerja dengan produktif bagi kepentingan organisasi (Sunyoto,2012:30) lalu apabila setiap anggota organisasi berperilaku sesuai dengan budaya yang berlaku maka akan diterima oleh lingkungannya sehingga akan menimbulkan kepuasan untuk bekerja secara optimal. Hasil tersebut sesuai dengan penelitian Fauzi (2017) dengan judul Pengaruh Kompensasi Dan Lingkungan Kerja Terhadap Kepuasan Kerja Karyawan PT. TOR Ganda Medan. Hasil menunjukkan lingkungan kompensasi dan lingkungan kerja berpengaruh positif terhadap kepuasan kerja karyawan.

Hasil uji koefisien determinasi diketahui nilai Adjusted R Square sebesar 0.434 atau 43,4\%. Artinya 43,4\% kepuasan kerja karyawan PT. Estadana Venture Cabang Kotabunan Sulawesi Utara dapat dijelaskan oleh variabel kompensasi dan lingkungan kerja. Sedangkan sisanya sebesar $56,6 \%$ dipengaruhi variabel lain yang tidak di cantumkan dalam penelitian seperti: kepemimpinan, beban kerja, prestasi, pengembangan karir, dan lainlain.

\section{KESIMPULAN DAN SARAN}

Berdasarkan hasil penelitian yang telah dilakukan, kesimpulan dari penelitian ini adalah:

1. Kompensasi berpengaruh signifikan terhadap kepuasan kerja karyawan PT. Estadana Venture Cabang Kotabunan Sulawesi Utara.

2. Lingkungan kerja berpengaruh signifikan terhadap kepuasan kerja karyawan PT. Estadana Venture Cabang Kotabunan Sulawesi Utara.

3. Sebesar 43,4\% kepuasan kerja karyawan PT. Estadana Venture Cabang Kotabunan Sulawesi Utara dapat dijelaskan oleh variabel kompensasi dan lingkungan kerja. Sedangkan sisanya sebesar 56,6\% dipengaruhi variabel lain yang tidak di ada dalam penelitian. 
Berdasarkan kesimpulan diatas, maka saran yang dapat diberikan adalah sebagai berikut:

1. Saran bagi perusahaan:

a. Kompensasi sangat berpengaruh terhadap kepuasan kerja terutama untuk karyawan PT. Estadana Venture Cabang Kotabunan Sulawesi Utara. Maka kompensasi harus diberikan sesuai dengan hasil kerja atau kinerja serta prestasi yang diperoleh karyawan. Hal tersebut dapat membuat karyawan menjadi puas terhadap apa yang diberikan perusahaan dan meningkatkan motivasi kerja para karyawan agar lebih rajin lagi bekerja dan mendapatkan prestasi.

b. Pentingnya menjaga lingkungan kerja agar karyawan nyaman saat bekerja terutama fasilitas kerja yang diberikan seperti ruang tunggu karyawan yang dibuat nyaman, memberi fasilitas cofee break pada karyawan dan selalu menjaga kebersihan lingkungan. Menciptakan suasana kerja yang nyaman dengan menerapkan sikap keterbukaan antar karyawan maupun terhadap atasan.

2. Saran bagi peneliti selanjutnya:

Perlu mempertimbangkan faktor atau variabel lain yang turut mempengaruhi kepuasan kerja karyawan seperti: kepemimpinan, pengembangan karier, dll.

\section{DAFTAR PUSTAKA}

Afifudin, H. (2013). Dasar - Dasar Manajemen. CV. Bandung : CV. Mandar Maju

Arikunto, Suharsimi, (2010), Prosedur Penelitian Suatu Pendekatan Praktek, Jakarta: Penerbit Rineka Cipta

Fauzi. (2017).Pengaruh Kompensasi Dan Lingkungan Kerja Terhadap Kepuasan Kerja Karyawan PT. TOR GANDA MEDAN

Febriana Dewi. (2012).Pengaruh Kepemimpinan, Kompensasi Dan Budaya Organisasi Terhadap Kepuasan Kerja Karyawan

Ghozali, Imam. (2009). Aplikasi Analisis Multivariate Dengan Program SPSS. 'Cetakan Keempat. Semarang: Badan Penerbit Universitas Diponegoro

Ghozali, Imam. (2013). Aplikasi Analisis Multivariate dengan Program SPSS, Edisi Ketujuh, Semarang: Badan Penerbit Universitas Diponegoro

Handoko, Hani. (2003). Manajemen Personalia dan Sumber Daya Manusia. Yogyakarta : Penerbit BPFE

Hariandja, M, (2005), Manajemen Sumber Daya Manusia, Pengadaan, Pengembangan, Pengkompensasian, dan Peningkatan Produktivitas Pegawai, Jakarta: PT. Grasindo, Cetakan Ketiga

Hasibuan. (2011). Manajemen Sumber Daya Manusia. Jakarta : Bumi Aksara Jakarta : Kencana 
Fakultas Ekonomi, Universitas Cokroaminoto Yogyakarta

Mangkunegara, Anwar Prabu. (2005). Manajemen Sumber Daya Manusia Perusahaan. Cetakan Keenam. PT Remaja Rosdakarya . Bandung Marwansyah. (2010). Manajemen Sumber Daya Manusia. Edisi Kedua. Bandung : Alfabeta

Nawawi, Hadari, (2005), Manajemen Sumber Daya Manusia untuk Bisnis yang Kompetitif, Yogyakarta: Gadjah Mada University Press

Pamungkas (2013) Pengaruh Budaya Organisasi Dan Kompensasi Terhadap Kepuasan Kerja Dan Kinerja Pegawai STMIK Adi Unggul Bhirawa (AUB) Surakarta

Simamora, Henry. (2002) Manajemen Sumber Daya Manusia. PT Gramedia Pustaka Umum, Jakarta

Sugiyono, (2010), Metode Penelitian Kunatitatif Kualitatif dan R\&D, Bandung: Alfabeta

Sugiyono. (2013). Metode Penelitian Kuantitatif Kualitatif dan $R \&$ D. Bandung : Rosdakarya

Sutrisno, Edy. (2013). Manajemen Sumber Daya Manusia. Edisi Pertama. Cetakan Pertama

Tegar Mangkulangit (2014) Pengaruh Lingkungan Kerja, Kompensasi Dan Kepemimpinan Terhadap Kepuasan Kerja Karyawan Pada PT. BPR Weleri Jayapersada Kendal

Yoky Suryo Prayogo (2015). Analisis Pengaruh Lingkungan Kerja Dan Budaya Organisasi Terhadap Kepuasan Kerja Karyawan RSI Sultan Agung Semarang 